\title{
Analysis of Antidepressant Use in Republic of Serbia from 2013 to 2015
}

\author{
Boris Ž. Milijašević́ ${ }^{1}$ Andreja L. Vlajankov ${ }^{1}$, Milan B. Ubavić², \\ Aleksandar L. Rašković ${ }^{1}$, Nikola B. Martić ${ }^{1}$, Zdenko S. Tomić ${ }^{1}$ \\ ${ }^{1}$ Department of Pharmacology, Toxicology and Clinical Pharmacology, Faculty of Medicine, \\ University of Novi Sad, Novi Sad, Serbia \\ ${ }^{2}$ Institute for Laboratory Diagnostics, Medlab, Novi Sad, Serbia
}

\section{SUMMARY}

Introduction: Depression is a chronic mental disorder that causes changes in mood, thoughts, behavior and physical health. According to the World Health Organization (WHO) 350 million people worldwide are said to suffer from this mental disorder. This explains why antidepressants are widely used.

Aim: The aim of this study was to analyze the use of antidepressants in Serbia, Norway and Finland from 2013 to 2015.

Methods: The data about the use of antidepressants in Serbia, Norway and Finland in 2013, 2014 and 2015 was taken from the Agency for Drugs and Medical Devices of the Republic of Serbia, the sites of Norwegian Institute of Public Health, and Finish Agency for Drugs Fimea.

Results: Large number of depressed patients and smaller number of antidepressants used in Serbia compared to Finland and Norway in 2013, 2014 and 2015 can be explained by a different socioeconomic status and different health system in those three countries. Patients in Serbia are underdiagnosed and undertreated due to a failure of the primary care physicians to identify depressed patients, so that those can be treated by a psychiatrist at the secondary health care level. Sertralin is the first-choice medication in Serbia compared to escitalopram in Norway and Finland. Escitalopram has the highest probability of remission of the investigated antidepressants and is the most effective and cost-effective pharmacological treatment strategy for depression in a primary care setting.

Conclusion: The consumption of antidepressants in Serbia increased in 2015 compared to 2013, but was still significantly less in Serbia in 2013, 2014 and 2015 compared to Finland and Norway, pharmacotherapeutically developed countries. Medications consumed the most in all 3 countries in 2013, 2014 and 2015 were selective serotonin reuptake inhibitors. Sertraline was the most widely used antidepressant in Serbia in 2015, while escitalopram was mostly used antidepressant in Norway and Finland.

Keywords: depression, antidepressants, pharmacoepidemiology 


\section{INTRODUCTION}

Depression is a chronic mental disorder that causes changes in mood, thoughts, behavior and physical health. According to the World Health Organization (WHO) 350 million people worldwide are said to suffer from this mental disorder. The lifetime prevalence for major depression is reported to be as high as $14-17 \%$ and the one-year prevalence is $4-8 \%$. The lifetime prevalence rates of major depressive disorders among women are $10-25 \%$, and for men 5-12\%. Depression is one of the leading causes of disability- adjusted life year (DALY) $[1,2]$.

The most common forms of depression are the following:

Persistent depressive disorder (also called dysthymia) is a depressed mood that lasts for at least two years. A person diagnosed with persistent depressive disorder may have episodes of major depression along with periods of less severe symptoms, but symptoms must last for two years to be considered persistent depressive disorder.

Postpartum depression - women with postpartum depression experience full-blown major depression during pregnancy or after delivery (postpartum depression). The feelings of extreme sadness, anxiety, and exhaustion that accompany postpartum depression may make it difficult for these new mothers to complete daily care activities for themselves and/or for their babies.

Psychotic depression occurs when a person has severe depression plus some form of psychosis, such as having disturbing false fixed beliefs (delusions) or hearing or seeing upsetting things that others cannot hear or see (hallucinations). The psychotic symptoms typically have a depressive "theme," such as delusions of guilt.

Seasonal affective disorder is characterized by the onset of depression during the winter months, when there is less natural sunlight. This depression generally lifts during spring and summer. Winter depression, typically accompanied by social withdrawal, increased sleep, and weight gain, predictably returns every year in seasonal affective disorder.

Bipolar disorder is different from depression, but it is included in this list is because someone with bipolar disorder experiences episodes of extremely low moods that meet the criteria for major depression (called "bipolar depression"). But a person with bipolar disorder also experiences extreme high - euphoric or irritable - moods called "mania" or a less severe form called "hypomania" [1].

Depression can only be diagnosed if the following symptoms are present most of the day, almost every day for at least 2 weeks: loss of interest or pleasure in hobbies and activities and persistent sad, anxious, or "empty" mood. These symptoms have to be accompanied by at least 4 of the following symptoms: feelings of hopelessness, or pessimism, irritability, feelings of guilt, worthlessness, or helplessness, decreased energy or fatigue, moving or talking slowly, feeling restless or having trouble sitting still, difficulty concentrating, remembering, or making decisions, difficulty sleeping, earlymorning awakening, or oversleeping, appetite and/or weight changes, thoughts of death or suicide, or suicide attempts, aches or pains, headaches, cramps, or digestive problems without a clear physical cause and/or that do not ease even with treatment $[1,2]$.

Current research suggests that depression is caused by a combination of genetic, biological, environmental, and psychological factors. Depression can happen at any age, but often begins in adulthood [1].

Depression, especially in midlife or older adults, can co-occur with other serious medical illnesses, such as diabetes, cancer, heart disease, and Parkinson's disease. But, in younger people, depression is often associated with rheumatoid arthritis and other chronic inflammatory disorders [3]. These conditions are often worse when depression is present. Sometimes medications taken for these physical illnesses may cause side effects that contribute to depression [1].

Risk factors include: personal or family history of depression, major life changes, trauma, or stress and certain physical illnesses and medications [1].

Depression is usually treated with medications, psychotherapy, or a combination of the two. If these treatments do not reduce symptoms, electroconvulsive therapy (ECT) and other brain stimulation therapies may be options to explore [1].

Medications that modulate monoaminergic neurotransmitter function by one mechanism or another can possess antidepressant efficacy, as demonstrated in multiple randomized, double-blind, controlled trials. Such 
medications include the tricyclic/tetracyclic antidepressants (TCAs), monoamine oxidase inhibitors (MAOIs), selective serotonin (5-HT) reuptake inhibitors (SSRIs), 5-HT and norepinephrine (NE) dual-reuptake inhibitors (SNRIs), and several atypical antidepressants (e.g., nefazodone, bupropion, and mirtazapine). Mechanisms of action for these medications primarily include the following:

1) inhibiting reuptake of $\mathrm{NE}$ and/or 5-HT into the presynaptic terminal from the synapse (TCAs, SSRIs, and SNRIs);

2) inhibiting monoamine oxidase, the enzyme that degrades 5-HT, NE, and dopamine (DA) in the presynaptic terminal (MAOIs);

3) blocking or stimulating presynaptic and/or postsynaptic monoamine neurotransmitter receptors (mirtazapine, nefazodone, trazodone, and several atypical antipsychotics) [4].

The most popular types of antidepressants are called selective serotonin reuptake inhibitors (SSRIs). Accumulation of data on serotonergic organization and function of the Central Nervous System in healthy and morbid conditions has largely improved the understanding of etiopathogenesis of the affective and cognitive disorders. Concurrently, therapeutic approach has become more selective, specific and efficient, yet not more causal. [5]. Examples of SSRIs include: fluoxetine, citalopram, sertraline, paroxetine, escitalopram. Other types of antidepressants are serotonin and norepinephrine reuptake inhibitors (SNRIs). SNRIs are similar to SSRIs and include venlafaxine and duloxetine [1].

Another antidepressant that is commonly used is bupropion. Bupropion is a third type of antidepressant which works differently than either SSRIs or SNRIs. Bupropion is also used to treat seasonal affective disorder and to help people stop smoking [1].

SSRIs, SNRIs, and bupropion are popular because they do not cause as many side effects as older classes of antidepressants, and seem to help a broader group of depressive and anxiety disorders. Older antidepressant medications include tricyclics, tetracyclics, and monoamine oxidase inhibitors (MAOIs). For some people, tricyclics, tetracyclics, or MAOIs may be the best medications [1].

\section{AIM}

The aim of this study was to analyze the use of antidepressants from pharmacotherapeutic point of view in Serbia, Norway and Finland from 2013 to 2015 as well as to compare results of antidepressant use from Serbia with results of antidepressant use in Norway and Finland, countries with developed pharmacotherapeutic practice.

\section{METHODS}

The data about the use of antidepressants in Serbia in 2013, 2014 and 2015 was taken from the Agency for Drugs and Medical Devices of the Republic of Serbia [6-8]. The data on use of antidepressants in Norway and Finland was taken from the official site of the Norwegian Institute of Public Health and the official site of the Finish Agency for Drugs Fimea, respectively $[9,10]$. Analysis of the use of drugs was done from the point of social perspective and there was no influence of any factors or any interest groups.

Internationally recognized and widely accepted methodology in the study of drug use is based on the concept of anatomicaltherapeutic-chemical classification of drugs (ATC) and defined daily doses. According to the ATC classification the drugs that we use in treatment of nervous system belong to the $\mathrm{N}$ group, whereas psychoanaleptics are belonging to a group of N06. Antidepressants are further analyzed in N06A group.

In order to facilitate comparison of the intensity of use of certain drugs in time and in different geographical areas scientist created a separate statistical unit of measurement of drug use, labeled as defined daily doses (DDD). The unit is independent of price, size, packaging, protected names of individual manufacturers and even from the pharmaceutical dosage form. The concept of DDD offered as a statistical unit of use the agreed amount of drug that is commonly used for the most common indication. DDD is defined, whenever its possible, in weight units (or units of activity). The amount of the drug used is expressed in the number of defined daily doses (DDD) per 1000 inhabitants per day (DDD/1000 inhabitants/day) [11].

\section{RESULTS}

Consumption of antidepressants (N06A) in Serbia in 2013 was 18.34 DDD/1000 inhabitants/day, while in 2015 it was $26.13 \mathrm{DDD} / 1000$ inhabitants/day; there was an increase of anti- 
Table 1. Comparative review of antidepressant use (N06A) in Serbia from 2013 to 2015 expressed in DDD/inhabitants/ day and percentage

DDD - DDD/1000 inhabitants/ day

\begin{tabular}{|c|c|c|c|c|c|c|c|}
\hline & Country & & & Ser & & & \\
\hline & Year & 20 & & 20 & & 20 & \\
\hline $\begin{array}{l}\text { ATC } \\
\text { group }\end{array}$ & INN & DDD & $\%$ & DDD & $\%$ & DDD & $\%$ \\
\hline N06A & antidepressants & 18.34 & 100.00 & 14.39 & 100.00 & 26.13 & 100.00 \\
\hline N06AA & $\begin{array}{l}\text { non-selelective monomamine } \\
\text { reuptake inhibitors }\end{array}$ & 1.51 & 8.23 & 1.39 & 9.66 & 1.54 & 5.89 \\
\hline N06AA04 & clomipramine & 0.39 & 2.13 & 0.36 & 2.50 & 0.35 & 1.34 \\
\hline N06AA06 & trimipramine & - & - & - & - & - & - \\
\hline N06AA09 & amitriptyline & 0.33 & 1.80 & 0.29 & 2.02 & 0.33 & 1.26 \\
\hline N06AA10 & nortriptyline & - & - & - & - & - & - \\
\hline N06AA12 & doxepin & - & - & - & - & - & - \\
\hline N06AA21 & maprotiline & 0.79 & 4.31 & 0.74 & 5.14 & 0.86 & 3.29 \\
\hline N06AB & $\begin{array}{l}\text { selective serotonin reuptake } \\
\text { inhibitors }\end{array}$ & 14.2 & 77.43 & 9.94 & 69.08 & 20.71 & 79.26 \\
\hline N06AB03 & fluoxetine & 2.12 & 11.56 & 0.51 & 3.54 & 2.89 & 11.06 \\
\hline N06AB04 & citalopram & 0.75 & 4.09 & 0.81 & 5.63 & 1.15 & 4.40 \\
\hline N06AB05 & paroxetine & 3.04 & 16.58 & 3.31 & 23.00 & 4.08 & 15.61 \\
\hline N06AB06 & sertraline & 6.34 & 34.57 & 2.01 & 13.97 & 8.20 & 31.38 \\
\hline N06AB08 & fluvoxamine & - & - & - & - & - & - \\
\hline N06AB10 & escitalopram & 1.95 & 10.63 & 3.31 & 23.00 & 4.39 & 16.80 \\
\hline N06AG & $\begin{array}{l}\text { monoaminoxidase inhibitors A } \\
\text { (MAO-A) }\end{array}$ & 0.01 & 0.05 & 0.01 & 0.07 & 0.01 & 0.04 \\
\hline N06AG02 & moclobemide & 0.01 & 0.05 & 0.01 & 0.07 & 0.01 & 0.04 \\
\hline N06AX & other antidepressants & 2.62 & 14.29 & 3.04 & 21.13 & 3.86 & 14.77 \\
\hline N06AX03 & mianserin & 0.36 & 1.96 & 0.29 & 2.02 & 0.36 & 1.38 \\
\hline N06AX05 & trazodone & 0.6 & 3.27 & 0.52 & 3.61 & 0.77 & 2.95 \\
\hline N06AX11 & mirtazapine & 0.84 & 4.58 & 1.36 & 9.45 & 1.84 & 7.04 \\
\hline N06AX12 & bupropion & 0.03 & 0.16 & 0.03 & 0.21 & 0.03 & 0.11 \\
\hline N06AX14 & tianeptine & 0.04 & 0.22 & 0.03 & 0.21 & 0.03 & 0.11 \\
\hline N06AX16 & venlafaxine & 0.75 & 4.09 & 0.83 & 5.77 & 0.82 & 3.14 \\
\hline N06AX17 & milnacipran & - & - & - & - & - & - \\
\hline N06AX18 & reboxetine & - & - & - & - & - & - \\
\hline N06AX21 & duloxetine & - & - & 0.00 & 0.00 & 0.00 & 0.00 \\
\hline N06AX22 & agomelatine & - & - & - & - & - & - \\
\hline N06AX26 & vortioxetine & - & - & - & - & - & - \\
\hline
\end{tabular}

depressant use in in Serbia in 2015 compared to 2013.

The most widely used antidepressant group in Serbia in 2013, 2014 and 2015 was the group of selective serotonin reuptake inhibitors (N06AB). In 2013, the use of selective serotonin reuptake inhibitors was 14.2 $\mathrm{DDD} / 1000$ inhabitants/day or $77.43 \%$ of all antidepressant use and in 2015 it was 20.71 $\mathrm{DDD} / 1000$ inhabitants/day or $79.26 \%$. Increase in use of selective serotonin reuptake inhibitors in Serbia in 2015 compared to 2013 is evident.
The most widely used antidepressant in Serbia in 2013 was sertralin (N06AB06) with $6.34 \mathrm{DDD} / 1000$ inhabitants/day or $34.57 \%$ of all antidepressant use and in 2015 it was 8.20 $\mathrm{DDD} / 1000$ inhabitants/day or $31.38 \%$. The use of sertraline increased in 2015 compared to 2013 .

The use of antidepressants (N06A) in 2013 in Norway was 56.64 DDD/1000 inhabitants/day and it decreased in 2015 to 56.48 DDD/1000 inhabitants/day.

In Norway and Serbia, selective serotonin reuptake inhibitors (N06AB) were most 


\begin{tabular}{|c|c|c|c|c|c|c|c|c|}
\hline \multirow{2}{*}{\multicolumn{2}{|c|}{$\begin{array}{c}\text { Country } \\
\text { Year }\end{array}$}} & \multicolumn{6}{|c|}{ Norway } & \multirow{3}{*}{$\begin{array}{l}\text { Table 2. Comparative review } \\
\text { of antidepressant use (N06A) } \\
\text { in Norway from } 2013 \text { to } 2015 \\
\text { expressed in DDD/inhabitants/ } \\
\text { day and percentage }\end{array}$} \\
\hline & & \multicolumn{2}{|c|}{2013} & \multicolumn{2}{|c|}{2014} & \multicolumn{2}{|c|}{2015} & \\
\hline $\begin{array}{l}\text { ATC } \\
\text { group }\end{array}$ & INN & DDD & $\%$ & DDD & $\%$ & DDD & $\%$ & \\
\hline N06A & antidepressants & 56.64 & 100.00 & 55.88 & 100.00 & 56.48 & 100.00 & DDD - DDD/1000 inhabitants/ \\
\hline N06AA & $\begin{array}{l}\text { non-selelective monomamine } \\
\text { reuptake inhibitors }\end{array}$ & 3.48 & 6.14 & 3.47 & 6.21 & 3.47 & 6.14 & day \\
\hline N06AA04 & clomipramine & 0.25 & 0.44 & 0.23 & 0.41 & 0.23 & 0.41 & \\
\hline N06AA06 & trimipramine & 0.34 & 0.60 & 0.31 & 0.55 & 0.29 & 0.51 & \\
\hline N06AA09 & amitriptyline & 2.58 & 4.56 & 2.63 & 4.71 & 2.68 & 4.75 & \\
\hline N06AA10 & nortriptyline & 0.13 & 0.23 & 0.14 & 0.25 & 0.14 & 0.25 & \\
\hline N06AA12 & doxepin & 0.17 & 0.30 & 0.15 & 0.27 & 0.13 & 0.23 & \\
\hline N06AA21 & maprotiline & - & - & - & - & - & - & \\
\hline N06AB & $\begin{array}{l}\text { selective serotonin reuptake } \\
\text { inhibitors }\end{array}$ & 37.47 & 66.15 & 36.59 & 65.48 & 36.94 & 65.40 & \\
\hline N06AB03 & fluoxetine & 2.14 & 3.78 & 2.17 & 3.88 & 2.25 & 3.98 & \\
\hline N06AB04 & citalopram & 4.75 & 8.39 & 4.31 & 7.71 & 4.06 & 7.19 & \\
\hline N06AB05 & paroxetine & 2.94 & 5.19 & 2.80 & 5.01 & 2.66 & 4.71 & \\
\hline N06AB06 & sertraline & 7.27 & 12.84 & 6.92 & 12.38 & 7.44 & 13.17 & \\
\hline N06AB08 & fluvoxamine & 0.10 & 0.18 & 0.10 & 0.18 & 0.10 & 0.18 & \\
\hline N06AB10 & escitalopram & 20.27 & 35.79 & 20.28 & 36.29 & 20.44 & 36.19 & \\
\hline N06AG & $\begin{array}{l}\text { monoaminoxidase inhibitors } A \\
\text { (MAO-A) }\end{array}$ & 0.15 & 0.26 & 0.14 & 0.25 & 0.13 & 0.23 & \\
\hline N06AG02 & moclobemide & 0.15 & 0.26 & 0.14 & 0.25 & 0.13 & 0.23 & \\
\hline N06AX & other antidepressants & 15.55 & 27.45 & 15.68 & 28.06 & 15.93 & 28.20 & \\
\hline N06AX03 & mianserin & 1.97 & 3.48 & 1.83 & 3.27 & 1.73 & 3.06 & \\
\hline N06AX05 & trazodone & - & - & - & - & - & - & \\
\hline N06AX11 & mirtazapine & 5.17 & 9.13 & 5.38 & 9.63 & 5.28 & 9.35 & \\
\hline N06AX12 & bupropion & 0.98 & 1.73 & 1.03 & 1.84 & 1.08 & 1.91 & \\
\hline N06AX14 & tianeptine & - & - & - & - & - & - & \\
\hline N06AX16 & venlafaxine & 6.95 & 12.27 & 6.91 & 12.37 & 7.09 & 12.55 & \\
\hline N06AX17 & milnacipran & - & - & - & - & - & - & \\
\hline N06AX18 & reboxetine & 0.04 & 0.07 & 0.04 & 0.07 & 0.03 & 0.05 & \\
\hline N06AX21 & duloxetine & 0.45 & 0.79 & 0.49 & 0.88 & 0.57 & 1.01 & \\
\hline N06AX22 & agomelatine & - & - & - & - & - & - & \\
\hline N06AX26 & vortioxetine & - & - & 0.00 & 0.00 & 0.14 & 0.25 & \\
\hline
\end{tabular}

widely used group of antidepressants. Their use in 2013 was $37.47 \mathrm{DDD} / 1000$ inhabitants/ day or $66.15 \%$ of all antidepressant use and it decreased in 2015 to $36.94 \mathrm{DDD} / 1000$ inhabitants/day or $65.40 \%$

The most widely used antidepressant in Norway in 2013 was escitalopram (N06AB10) with $20.27 \mathrm{DDD} / 1000$ inhabitants/day or $35.79 \%$ of all antidepressant use, which corresponds to the results in 2015 (20.44 $\mathrm{DDD} / 1000$ inhabitants/day or $36.19 \%$ ) where the use of escitalopram was the highest as well. Escitalopram belongs to the group of selective serotonin reuptake inhibitors (N06AB). Escitalopram use increased in 2015 compared to 2013.

The use of antidepressants (N06A) in Finland in 2013 was 63.66 DDD/1000 inhabitants/day and it increased to $68.16 \mathrm{DDD} / 1000$ inhabitants/day in 2015.

The most widely used antidepressant group in Finland was selective serotonin reuptake inhibitors group which corresponds to the results from Norway and Serbia. The use of selective serotonin reuptake inhibitors in 2013 was $39.64 \mathrm{DDD} / 1000$ inhabitants/day or 
Table 3. Comparative review of antidepressant use (N06A) in Finalnd from 2013 to 2015 expressed in DDD/inhabitants/ day and percentage

DDD - DDD/1000 inhabitants/ day

\begin{tabular}{|c|c|c|c|c|c|c|c|}
\hline \multirow{2}{*}{\multicolumn{2}{|c|}{$\frac{\text { Country }}{\text { Year }}$}} & \multicolumn{6}{|c|}{ Finalnd } \\
\hline & & \multicolumn{2}{|c|}{2013} & \multicolumn{2}{|c|}{2014} & \multicolumn{2}{|c|}{2015} \\
\hline $\begin{array}{l}\text { ATC } \\
\text { group }\end{array}$ & INN & DDD & $\%$ & DDD & $\%$ & DDD & $\%$ \\
\hline N06A & antidepressants & 63.66 & 100.00 & 65.32 & 100.00 & 68.16 & 100.00 \\
\hline N06AA & $\begin{array}{l}\text { non-selelective monomamine } \\
\text { reuptake inhibitors }\end{array}$ & 3.76 & 5.91 & 3.94 & 6.03 & 4.22 & 6.19 \\
\hline N06AA04 & clomipramine & 0.21 & 0.33 & 0.20 & 0.31 & 0.21 & 0.31 \\
\hline N06AA06 & trimipramine & 0.12 & 0.19 & 0.12 & 0.18 & 0.11 & 0.16 \\
\hline N06AA09 & amitriptyline & 2.59 & 4.07 & 2.70 & 4.13 & 2.95 & 4.33 \\
\hline N06AA10 & nortriptyline & 0.4 & 0.63 & 0.43 & 0.66 & 0.46 & 0.67 \\
\hline N06AA12 & doxepin & 0.45 & 0.71 & 0.50 & 0.77 & 0.49 & 0.72 \\
\hline N06AA21 & maprotiline & - & - & - & - & - & - \\
\hline N06AB & $\begin{array}{l}\text { selective serotonin reuptake } \\
\text { inhibitors }\end{array}$ & 39.64 & 62.27 & 39.49 & 60.46 & 39.77 & 58.35 \\
\hline N06AB03 & fluoxetine & 3.72 & 5.84 & 3.95 & 6.05 & 4.12 & 6.04 \\
\hline N06AB04 & citalopram & 13.78 & 21.65 & 12.60 & 19.29 & 12.03 & 17.65 \\
\hline N06AB05 & paroxetine & 2.52 & 3.96 & 2.50 & 3.83 & 2.45 & 3.59 \\
\hline N06AB06 & sertraline & 6.08 & 9.55 & 6.46 & 9.89 & 7.18 & 10.53 \\
\hline N06AB08 & fluvoxamine & 0.21 & 0.33 & 0.20 & 0.31 & 0.19 & 0.28 \\
\hline N06AB10 & escitalopram & 13.34 & 20.96 & 13.77 & 21.08 & 13.80 & 20.25 \\
\hline N06AG & $\begin{array}{l}\text { monoaminoxidase inhibitors A } \\
\text { (MAO-A) }\end{array}$ & 0.44 & 0.69 & 0.41 & 0.63 & 0.39 & 0.57 \\
\hline N06AG02 & moclobemide & 0.44 & 0.69 & 0.41 & 0.63 & 0.39 & 0.57 \\
\hline N06AX & other antidepressants & 19.81 & 31.12 & 21.49 & 32.90 & 23.79 & 34.90 \\
\hline N06AX03 & mianserin & 0.38 & 0.60 & 0.38 & 0.58 & 0.40 & 0.59 \\
\hline N06AX05 & trazodone & 0.11 & 0.17 & 0.13 & 0.20 & 0.14 & 0.21 \\
\hline N06AX11 & mirtazapine & 7.60 & 11.94 & 7.82 & 11.97 & 8.35 & 12.25 \\
\hline N06AX12 & bupropion & 1.13 & 1.78 & 1.39 & 2.13 & 1.53 & 2.24 \\
\hline N06AX14 & tianeptine & - & - & - & - & - & - \\
\hline N06AX16 & venlafaxine & 8.04 & 12.63 & 8.71 & 13.33 & 9.69 & 14.22 \\
\hline N06AX17 & milnacipran & 0.05 & 0.08 & 0.06 & 0.09 & 0.06 & 0.09 \\
\hline N06AX18 & reboxetine & 0.05 & 0.08 & 0.05 & 0.08 & 0.04 & 0.06 \\
\hline N06AX21 & duloxetine & 2.08 & 3.27 & 2.46 & 3.77 & 2.73 & 4.01 \\
\hline N06AX22 & agomelatine & 0.36 & 0.57 & 0.49 & 0.75 & 0.59 & 0.87 \\
\hline N06AX26 & vortioxetine & - & - & - & - & 0.26 & 0.38 \\
\hline
\end{tabular}

$62.27 \%$ of all antidepressant use. In 2015, the result was $39.77 \mathrm{DDD} / 1000$ inhabitants/day or $58.35 \%$.

The most widely used antidepressant in Finland in 2013 was Citalopram (N06AB04) with $13.78 \mathrm{DDD} / 1000$ inhabitants/day or $21.65 \%$ of all antidepressant use, while in 2015 that was escitalopram (N06AB10) with 13.80 DDD/1000 inhabitants/day or $20.25 \%$.

\section{DISCUSSION}

Comparison of use and prices of prescribed medications for treatment of depression to countries with developed pharmacotherapeutic practice is giving a possibility to review pharmacotherapeutic practice of one country and its dynamics during a certain time frame, which can be important for establishing future pharmacotherapeutic recommendations.

According to the WHO data from 2015, 40 million Europeans are suffering from depression. There was 419,302 cases of depression in Serbia in 2015 which is roughly 5\% of the population. The very same year in Norway, there was 227,446 cases of depression which 
is $4.7 \%$ of the population while Finland had 293,921 cases identified or $5.6 \%$ of the population. Depression is one of the leading causes of the disability among the psychiatric diseases in Europe with the annual cost of 115 billion $€$ [12].

The use of antidepressants (N06A) in Serbia in 2015 was $26.13 \mathrm{DDD} / 1000$ inhabitants/day, while in Norway it was 56.48 $\mathrm{DDD} / 1000$ inhabitants/day. The use of antidepressants in Finland was 68.16 DDD/1000 inhabitants/day in 2015.

According to the previously given information, the number of patients suffering from depression is much higher in Serbia than in Scandinavian countries, but the use of antidepressants is much lower.

According to Harhai's research, it was shown that barriers in diagnosing and treating depression are mostly due to the following reasons: general practitioners are overloaded with many visits, lack of competence to manage depression, and patient refusal to accept the diagnosis and treatment. To improve the recognition and treatment of depression in primary health care, it is necessary to provide better education programs for general practitioners, more time for work (by decreasing number of visits), and destigmatization, to motivate patients to talk about mental health problems and to accept the recommended treatment [13].

According to Stojancevic at al, the differences in antidepressant utilization between Serbia and Finland are partly consequential to different socioeconomic and health policy factors. The considerably lower utilization of antidepressants in Serbia implies possible underdiagnosing of affective disorders in general practice. Serious consequences may be reduced by early diagnosis, timely, adequate, and effective management of depression [14].

There is realitively small number of patients currently treated on the primary care level for depression in Serbia, meaning that only $39 \%$ of the patients who visits psychiatrist contact the primary care physician beforehand. The knowledge of the primary care physicians about the prevention and treatment of mental health disorders are not sufficient and the communication with the secondary health care level is inadequate or it does not exist at all. National budget for mental health is insufficient and the financing is still based on the number of bed days, while the preven- tion and the promotion of the mental health is inadequately supported. Centers for the mental health protection should be formed in certain territories of the country for mental health of the patients to be protected. Those centers should have teams for helping vulnerabile population, especially children, and adolescents through the support system outside of the health care insitututions, in schools and boarding schools. There are no protected apartments for these patients and there is no system in place that would guarantee employment of the psychiatric patients, so the circle of unemployment - poverty -depression cannot be stopped [15].

The Nordic countries are all established welfare states, and there has for some time existed a notion of a distinctive Nordic or Scandinavian welfare state; it is often understood in terms of broad, tax-financed public responsibility and legislated, collective, and universalistic solutions that respect employment interest yet aim at welfare and equity goals. Lately, the Nordic countries have performed well in comparative research of health policy in European countries but also regarding health care system in OECD countries. However, while it appears that the case for the existence of a Nordic model is strong there is no consensus of the precise specification of the feature that defines the model [16].

For example, considerable differences seem to exist between the psychiatric services within, as well as between Nordic countries when it comes to history, mental health acts and allocation of resources. Furthermore, some scholars argue that it is not even possible to speak of a common Nordic political approach to public health, since the public health programs in different Nordic countries contain contradictory policies and ideological statements This is especially evident for depression and sales of antidepressants in different Nordic countries [16].

Several factors such as accessibility of drugs, available treatment alternatives, clinical practice and national guidelines, may influence patterns of prescribing and use of antidepressant drugs in Nordic countries [16].

Further research is therefore needed to scrutinize as to why differences in prevalence of depression and antidepressant sales exist between the Nordic countries, despite the Nordic model. The Nordic countries do for some reason have a high consumption of anti- 
depressants compared to OECD despite relatively moderate or low depression prevalence patterns. This is especially important, since the increase in antidepressants consumption has spurred an ongoing debate whether antidepressants are overprescribed (medicalization) or under-prescribed (poor access to treatment) [16].

If we are to compare the use of antidepressants in Serbia, Norway and Finland in 2015 , it was determined that the use of selective serotonin reuptake inhibitors is the highest and these results correspond to national gudeliens for depression treatment. Sertralin was moslty used medication in Serbia with $8.20 \mathrm{DDD} / 1000$ inhabitants/day or $31.38 \%$. In Norway and Finland that was escitalopram with $20.44 \mathrm{DDD} / 1000$ inhabitants/day or $36.19 \%$ and $13.80 \mathrm{DDD} / 1000$ inhabitants/day or $20.25 \%$, respectively.

According to Ramsber at al, employing a large body of randomized head-tohead evidence, escitalopram has the highest probability of remission of the investigated antidepressants and is the most effective and cost-effective pharmacological treatment strategy for moderate to severe depression in a primary care setting, when evaluated over a one-year time-horizon [17]. According to the data obtained from the Republic of Serbia Health Insurance Funds, both escitalopram and sertraline are on the A list of medications. According to the documentation from the list of medications that have been funded by the obligated health insurance in 2015, the price of sertraline in bulk per DDD was 11.91 dinars and the price of escitalopram was 11.92 dinars. Copay for both medications was 50.00 dinars [18].

\section{CONCLUSION}

The use of antidepressants in Serbia increased in 2015 compared to 2013 and was significantly less in Serbia in 2013, 2014 and 2015 compared to Finland and Norway, pharmacotherapeutically developed countries. Medications used the most in all 3 counrties in 2013, 2014 and 2015 were selective serotonin reuptake inhibitors. Sertralin was the most widely used antidepressant in Serbia in 2015, while escitalopram was mostly used antidepressant in Norway and Finland.

\section{ACKNOWLEDGEMENT}

This research was supported by HORIZON2020 MEDLEM project No. 690876, the Project for Scientific and Technological Development of Vojvodina No. 114-451-207212016-02 and by the Ministry of Education, Science and Technological Development, Republic of Serbia, Project No 41012.

\section{REFERENCES}

1. Depression (quoted on 04Mar2018). Available on: https://www.nimh.nih.gov/health/topics/depression/index.shtml

2. Fekadu et al. Major Depressive Disorder: Pathophysiology and Clinical Management. Depress Anxiety 2017, 6:1

3. Lapcević M, Vuković M, Grozdenović BS, Mioljević $\mathrm{V}$, Marjanović S. Socioeconomic and therapy factor influence on self-reported fatigue, anxiety and depression in rheumatoid arthritis patients. Revista Brasileira de Reumatologia 2017; 57(6):545-56

4. Holtzheimer PE, Nemeroff CB (2008) Novel Targets for Antidepressant Therapies. Curr Psychiatry Rep 10: 465-73.

5. Timotijević I, Stanković Ž, Todorović M, Marković SZ, Kastratović DA. Serotonergic organization of the central nervous system. Psychiatr Danub. 2012 Oct;24 Suppl 3:S326-30.

6. Republic of Serbia. Medicines and Medical Devices Agency of Serbia. Consumption of Medicines 2013 (hard copy in Serbian language). Agency: Belgrade, 2014

7. Republic of Serbia. Medicines and Medical Devices Agency of Serbia. Consumption of Medicines 2014 (hard copy in Serbian language). Agency: Belgrade, 2015.

8. Republic of Serbia. Medicines and Medical Devices Agency of Serbia. Consumption of Medicines 2015 (hard copy in Serbian language). Agency: Belgrade, 2016

9. Norwegian Institute for Public Health. Drug Consumption in Norway 2010-2015. (quoted on 07Mar2018). Available on: http://www. legemiddelforbruk.no/english

10. Finnish Medicines Agency. Drug Consumption in Finland 2010-2015 (Quoted on 07Mar2018). Available on: http://www.fimea.fi/laaketieto/kulutustiedot

11. Perić $D$, Milijašević $D$, Tomić $N$, Knežević $A$, Bukumirović N, Milijašević B. Use of ACE-Inhibitors in Serbia in 2009 and 2010. Hospital Pharmacology-International Multidisciplinary Journal, 2014; 1(3):122-9. 
12. Depression and Other Common Mental Disorders: Global Health estimates (quoted on 07Mar2018). Available on: http://apps.who.int/ iris/bitstream/10665/254610/1/WHO-MSD-MER2017.2-eng.pdf

13. Barriers in Diagnosing Depression At The Primary Health Care Level in Serbia and Romania (quoted on 07Mar2018). Dostupno na:

h t t ps: / / ww w. researchgate.net / publication/301732565_BARRIERS_IN_DIAGNOSING_DEPRESSION_AT_THE_PRIMARY_HEALTH_ CARE_LEVEL_IN_SERBIA_AND_ROMANIA

14. Stojančević at al. Remarkably lower consumption of antidepressants in Serbia in comparison with Finland.BMC Pharmacol Toxicol. 2012; 13(Suppl 1): A5

15. Stanojević V. The Meaning of Depression in Public Health- Possibility of Intervention in Primary Care. PONS Med J 2016; 13(1):27-32

16. Vilhelmsson A. Depression and Antidepressants: A Nordic Perspective. Front Public Health. 2013; 1 : 30.

17. Ramsberg J, Asseburg C, Henriksson M (2012) Effectiveness and Cost-Effectiveness of Antidepressants in Primary Care: A Multiple Treatment Comparison Meta-Analysis and Cost-Effectiveness Model. PLoS ONE 7(8): e42003.

18. The list of the medications funded by the obligated health insurance in 2015 (quoted on 07Mar2018). Available on: http://obvrsac.com/wpcontent/uploads/2015/01/Lista-A-14102014.pdf 


\section{Analiza primene antidepresiva u Republici Srbiji od 2013. do 2015. godine}

Boris Ž. Milijašević ${ }^{1}$, Andreja L. Vlajankov ${ }^{1}$, Milan B. Ubavić ${ }^{2}$ Aleksandar L. Rašković1, Nikola B. Martić ${ }^{1}$, Zdenko S. Tomić ${ }^{1}$

${ }^{1}$ Zavod za farmakologiju, toksikologiju i kliničku farmakologiju, Medicinski fakultet Novi Sad, Univerzitet u Novom Sadu, Novi Sad, Srbija

${ }^{2}$ Zavod za laboratorijsku dijagnostiku, Medlab, Novi Sad, Srbija

\section{KRATAK SADRŽAJ}

Uvod: Depresija je hronično mentalno oboljenje koje uzrokuje promene rasploženja, ponašanja i razmišljanja. Prema podacima Svetske Zdravstvene Organizacije, 350 miliona ljudi na svetu pati od depresije. Ovo objašnjava zbog čega se antidepresivi primenjuju u velikoj meri.

Cilj: Cilj ovog istraživanja je analiza primene antidepresiva u Srbiji, Norveškoj i Finskoj u vremenskom periodu od 2013. do 2015. godine.

Metodologija: Podaci o primeni antidepresiva u Srbiji, Norveškoj i Finskoj tokom 2013., 2014. i 2015. godine dobijeni su iz Agencije za Lekove i Medicinska Sredstva Republike Srbije, oficijalnog sajta Norveškog Instituta za Javno Zdravlje i Finske Agencije za Lekove Fimea.

Rezultati: Veliki broj depresivnih pacijenata i mala primena antidepresiva u Srbiji u poređenju sa Finskom i Norveškom u 2013., 2014, i 2015. godini objašnjava se različitim socioekonomskim statusom i različitim zdravstvenim sistemom u Srbiji u poređenju sa Norveškom i Finskom. Pacijenti u Srbiji su nedovoljno dijagnostikovani i nedovoljno lečeni zbog neuspeha lekara opšte prakse na primarnom nivou zdravstvene zaštite da prepoznaju depresivne pacijente, leče ili upute na lečenje u ustanove sekundarnog nivoa zdravstvene zaštite. Sertralin je prvo-primenjivani lek u Srbiji, a escitalopram u Norveškoj i Finskoj. Escitalopram je najefikasniji i najbolji u pogledu odnosa cene i efikasnosti lečenja depresije na nivou primarne zdravstvene zaštite.

Zaključak: Primena antidepresiva u Srbiji u porastu je u 2015. godini u odnosu na 2013. godinu., ali je bila značajno manja u Srbiji tokom 2013., 2014. i 2015. godine nego u Finskoj i Norveškoj, državama sa dobro razvijenom farmakoterapijskom praksom. Najviše korišćeni lekovi u sve tri države tokom 2013., 2014., i 2015. godine bili su selektivni inhibitori preuzimanja serotonina. Sertralin je bio najviše primenjivan lek u Srbiji tokom 2015. godine, a escitalopram u Norveškoj i Finskoj.

Ključne reči: depresija, antidepresivi, farmakoepidemiologija 